\title{
Modern under-water mass-transport processes and deposits in Lake Baikal: the Class@Baikal Project data report
}

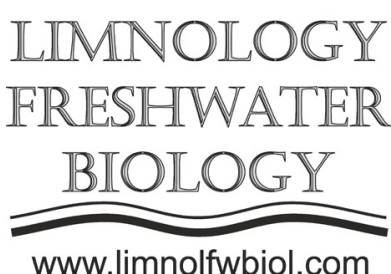

\author{
Solovyeva M.A. ${ }^{1 *}$, Akhmanov G.G. ${ }^{1}$, Bulanova I.A. ${ }^{1}$, Kudaev A.A. ${ }^{1}$, Egoshina E.D. ${ }^{1}$, \\ Khabuev A.V. ${ }^{2}$, Khlystov O.M. ${ }^{2}$
}

${ }^{1}$ Lomonosov Moscow State University, Leninskie Gory Str., 1, Moscow, 119991, Russia

${ }^{2}$ Limnological Institute, Siberian Branch of the Russian Academy of Sciences, Ulan-Batorskaya Str., 3, Irkutsk, 664033, Russia

\begin{abstract}
Mass-transport processes are abundant in the deep Lake Baikal. They form unique geological pattern of the lake and are responsible for various deposits. Four areas, where landslide and turbidite fan are developed, were studied in the framework of the Class@Baikal Project. As a result, a large deep-water fan Khuray was discovered and mapped. It characterized by a non-classical structure, that formed by the key influence of tectonic processes. The results of study of the Kukuy Griva and Krasnoyarskiy landslides allowed suggesting that landslide processes were activated in response to the dissociation of gas hydrates. Unique structures that have no analogues on Lake Baikal have been found at the Elovsky area. Their formation also occurred as the result of gravity processes, but the exact mechanism is still not known.
\end{abstract}

Keywords: mass-transport processes, landslides, gas hydrates, depositional systems, Lake Baikal.

\section{Introduction}

The annual international geological-geophysical expeditions of the Class@Baikal Project are carried out since 2014 on Lake Baikal. The main goals of studies are: focused discharge of hydrocarbons and gas hydrates forming, mass-transport and tectonic processes, features of sedimentation and others. The steep slopes of the Baikal basins, high tectonic activity and large volumes of supplied terrigenous material lead to widespread and intensive development of masstransport processes, leading to the formation of specific sediments and geological objects.

\section{Material and methods}

This study is based on an integration of geological and geophysical methods. Extensive seismic studies were carried out using chirp profilers and spark sources in the expeditions of the Class@Baikal Project from 2014 to 2019. The obtained materials allowed us to study in details both the general structure of the sedimentary section and the bottom sediments. Additionally, sidescan sonar surveys were performed on some areas. Bottom sediments also were studied during sampling with gravity cores. A lithological description of the sediment, gas-geochemical analysis, x-ray tomography and grain-size analysis were performed for all selected cores.

\section{Results and Discussion}

The studies were focused onto the Central and Southern basins of Lake Baikal, near the Selenga river Delta. As a result, large landslide amphitheatre, modern and buried landslide bodies, structures of sediment deformation and other characteristic features indicating active mass transport depositing were found on prodelta and delta front slopes of the Selenga River. The most interesting objects of this study were Kukuy Griva, Krasny Yar, Khuray and Elovsky areas. Their study allows us to note the features of modern gravity processes and the structures formed by them.

\subsection{Seeps and Krasnoyarskiy underwater land- slide}

Mass-transport processes formed a large landslide amphitheatre (about $10 \mathrm{~km}^{2}$ ) on the eastern slope of the prodelta of Selenga river. Also there are secondary small landslides. An amazing feature of this landslide is the location of an active zone of focused fluid discharge at its base. It is a group of seeps, whose activity is accompanied by the formation of nearsurface gas hydrates. This fact allowed us to suggest that the instability of slope deposits is associated with their increased gas saturation (Akhmanov and Khlystov, 2015). This theory is confirmed by detecting fluid

*Corresponding author.

E-mail address: marina-sol@yandex.ru (M.A. Solovyeva)

(C) Author(s) 2020. This work is distributed under the Creative Commons Attribution 4.0 License. 
migration channels in the sediments of the landslide, which are typical of gas-saturated sediments of Lake Baikal. The results of computer modeling also assume that the landslide deposits were initially strongly gas-saturated (Kudaev, 2018).

\subsection{Landslide slope of Kukuy Griva}

The Kukuy Griva is characterized by a wide development of landslide processes on its north-western slope. Both modern and large buried landslide bodies were discovered and mapped during the Class@Baikal expeditions (Solovyeva et al., 2016).

It is interesting to note that the slide head scarp is traced at a depth of about $360 \mathrm{~m}$, which is the upper limit of the zone of the gas hydrates stability. The head scarp of Krasny Yar landslide is located on the same depth. This fact can serve as an indirect evidence that the destabilization of the slopes and the activation of landslide processes could originate as a result of the destruction of gas hydrates during a decrease of sea level in the past.

\subsection{Elovsky area}

Unique geological objects were discovered at the foot of Posolsky Bank. It is local positive diapirlike structures on the bottom surface, composed of very dense and dry silty clay, which is not typical for the bottom sediments of Lake Baikal. A lot of new structures were discovered during the Class@Baikal expeditions. It was found that all of them are spatially confined to a buried large lense-like body of gravitational nature. The mechanism of formation of these structures has not yet been definitively described, but it seems that they have a genetic relationship with this body and owe their formation to the activity of mass-transport processes (Bulanova and Solovyeva, 2019).

\subsection{Deep-water depositional system Khuray}

A large deep-water sedimentary system was discovered during the Class@Baikal expeditions. It is occupied an area of about $1500 \mathrm{~km}^{2}$ and extending from the Kukuy canyon to cape Ukhan on the Olkhon island. The system is characterized by a complex structure of a valley-channel complex with braided channels that were developed under influence of active tectonic processes (Solovyeva et al., 2017). A massive complex of turbidite deposits was formed in the Central basin of the lake as a result of the Khuray system activity.

\section{Conclusions}

Underwater mass-trasport deposits are widespread on Lake Baikal, concentrating on the slopes of basins and at their foots. A wide variety of gravitational processes, with influence of other geological processes, leads to the formation of unique characteristics of sedimentary section.

\section{Acknowledgments}

This work was supported by RFBR grant No. 18-35-00363

\section{References}

Akhmanov G.G., Khlystov O.M. 2015. The Glass@ Baikal Project: developing the traditions of the International program «Training-through-Research (Floating University)». In: IV International Conference on Marine Research and Education, pp. 29-33. (in Russian)

Bulanova I.A., Solovyeva M.A. 2019. Diapir-like structures of the Elovsky area (Lake Baikal): possible mechanism of formation. In: International youth scientific forum «Lomonosov-2019». https://lomonosovmsu.ru/ archive/Lomonosov_2019/data/15897/94014_uid138515_ report.pdf (in Russian)

Kudaev A.A. 2018. Focused methane discharge as a cause of subaqual slope landslide (on the example of the Krasny Yar landslide on Lake Baikal). In: International Youth Scientific Forum «Lomonosov2018». https://lomonosovmsu. ru/archive/Lomonosov_2018/data/12854/65475_uid81763_ report.pdf (in Russian)

Solovyeva M.A., Starovoytov A.V., Akmanov G.G. et al. 2016. The evolution of slump-induced destruction of Kukuy Griva slope (Lake Baikal) revealed on the base of the data of seismic and acoustic surveys. Moscow University Geology Bulletin 71: 416-428. DOI: 10.3103/S0145875216060107

Solovyeva M.A., Pochevalova A.V., Akhmanov G.G. et al. 2017. Results of seismoacoustic studies of the deep-water sedimentary system Khuray (Lake Baikal). In: All-Russian Conference of Young Scientists «Complex Investigation of the World Ocean», pp. 526-527. (in Russian) 